\section{Genotoxic impact of a municipal effluent dispersion plume in the freshwater mussel Elliptio complanata: an in situ study}

\author{
E. Lacaze, ${ }^{1,2}$ A. Devaux, ${ }^{2}$ S. Bony, ${ }^{2}$ \\ A. Bruneau, ${ }^{1}$ C. André, ${ }^{1}$ M. Pelletier, ${ }^{3}$ \\ F. Gagné
}

'Emerging Methods Section, Environment Canada, Montreal, Quebec, Canada; 'LEHNA UMR 5023, INRA, USC IGH 1369, Université de Lyon, Vaulx en Velin, France; ${ }^{3}$ Water Quality Monitoring and Surveillance Division, Environment Canada, Montreal, Quebec, Canada

\section{Introduction}

Many surface waters have been reported to be contaminated whereas the most critical sources remain to be identified. The wastewater treatment plant (WWTP) effluents discharged in surface waters are one of the possible sources. Indeed, these effluents often contain well-known contaminants such as heavy metals, pesticides and polycyclic aromatic hydrocarbons, and emerging contaminants such as pharmaceuticals, personal care products, hormones and flame retardants. Although wastewaters are treated through different processes, a significant part of these xenobiotics is not eliminated by traditional urban WWTPs, leading to a risk for the aquatic ecosystems receiving these effluents. ${ }^{2}$ Given the chemical complexity of wastewater effluents, their toxicity remains hard to assess. The use of caged mussels has been proved to be a convenient and efficient approach to assess the biological effects of a discharge mixture in the field without prior information on its chemical composition. ${ }^{3}$ Particularly, the use of indigenous species such as Elliptio complanata is relevant to gain knowledge concerning wild species chronically exposed to the effluent. ${ }^{4,5}$ Genotoxicity endpoints deserve to be studied since it is noteworthy that genotoxic impacts can lead to heritable mutations with potentially detrimental effects on aquatic organism populations. ${ }^{6}$ The use of genotoxic endpoints is therefore relevant to assess the toxic impact of municipal effluents.

The aim of this study was to assess the potential genotoxic impact of a municipal effluent discharge on Elliptio complanata caged in the St Lawrence River. Mussels were caged upstream and downstream the effluent of the third largest municipal treatment plant in the world, which can support a flow rate about 2.5 to 7.6 million $\mathrm{m}^{3}$ per day. Recently, ozonation has been chosen to improve the wastewater treatment and might be operational in the coming years. The genotoxic impact of the effluent was studied on caged mussels whose the condition index and the hemocytes viability have been measured, displaying the general health status of organisms. Three biomarkers of damage were used on hemocytes, which are considered as a target cell type due to their direct contact with xenobiotics and their numerous roles as circulating cells. Hemocytes are in charge of the transport and digestion of nutrients and the organism defense by the immune response. ${ }^{7}$ Lipid peroxidation of membranes was analyzed as an oxidative stress index and DNA damage was assessed by the Comet assay and by the alkaline DNA precipitation method.

\section{Materials and Methods}

\section{Mussel handling and caging}

Elliptio complanata collected in a pristine site were allowed to depure for 2 months in laboratory at $15^{\circ} \mathrm{C}$ in filtered and dechlorinated water and fed daily with commercial algal nutrient mix (Phytoplex ${ }^{\circledR}$, KentMarine) and cultured Pseudokirchneriella subcapitata microalgae prior to caging experiment. For the experiment, two cages of ten mussels (average weight $63.5 \pm 11.2 \mathrm{~g}$ and shell length $85.8 \pm 7.8 \mathrm{~mm}$ ) were attached to sediment traps deployed during 30 days according to the Standard Guide for Conducting In-situ Field Bioassays With Caged Bivalves and to previous in situ-studies using Elliptio complanata. ${ }^{5}$ Seven sites were chosen in the St Lawrence River: 200 m upstream, $2 \mathrm{~km}$ downstream (site called Effluent), $10 \mathrm{~km}$ and 20 $\mathrm{km}$ downstream from the effluent input (sites called DS1, DS2, DS3, DS4, DS5) (Figure 1). Water parameters (temperature, $\mathrm{pH}$, conductivity, flow rate and suspended matter) were checked every week. At the end of the caging procedure, mussels were allowed to depure overnight in dechlorinated water at room temperature $\left(22^{\circ} \mathrm{C}\right)$. The weight and the shell length of the mussels were measured in order to determine the condition factor expressed as weight/shell length.

\section{Biomarkers}

Hemolymph was collected from the anterior adductor muscle with a 23G needle syringe. Hemocytes counting and viability were determined by flow cytometry (PCA Guava Cytometer) using the ViaCount solution kit (Guava Technologies, Hayward, CA, USA). At least 5000 events were acquired. Fifteen mussels per site were punctured.
Correspondence: Emile Lacaze, Emerging Methods Section, Environment Canada, Montreal, Quebec, Canada.

E-mail: emilie.lacaze@ec.gc.ca

Key words: genotoxic impact, municipal effluent, Elliptio complanata, caged organisms.

Conference presentation: part of this paper was presented at the ECOBIM meeting, 2013 May, Montréal, Quebec, Canada.

Acknowledgments: we are grateful to $M$. Arseneau and G. Brault for their help in the field, and to M. Gélinas and J. Auclair for their help in the laboratory.

This work is licensed under a Creative Commons Attribution NonCommercial 3.0 License (CC BYNC 3.0).

(C) Copyright E. Lacaze et al., 2013

Licensee PAGEPress, Italy

Journal of Xenobiotics 2013; 3(s1):e6

doi:10.4081/xeno.2013.sl.e6

Measurements of total protein content, lipid peroxidation and DNA damage in hemolymph were carried out on 8 mussels per site. The protein content was determined in cell free supernatant ( $9000 \mathrm{~g}, 10 \mathrm{~min})$ according to the Bradford method, ${ }^{8}$ using the BioRad Protein Assay and Bovine Serum Albumine as a standard. Lipid peroxidation (LPO) was measured in cell pellet $(1 \mathrm{~mL}$ of hemolymph centrifuged at $1000 \mathrm{~g}, 10 \mathrm{~min}$, withdrawal of $500 \mu \mathrm{L}$ of the supernatent) according to the thiobarbituric acid method. ${ }^{9}$ Thiobarbituric acid reactants were determined by fluorescence $(540 \mathrm{~nm} \mathrm{Ex}$ and $600 \mathrm{~nm} \mathrm{Em}$ ) and tetramethoxypropane was used for calibration. The levels of DNA strand breaks were determined in cell pellet by the alkaline DNA precipitation assay described by Olive (1988)..$^{10}$ The principle of the assay is based on the selective precipitation of nuclear DNA from the more soluble DNA strand fragments followed by the fluorescent detection of the stranded DNA remaining in the supernatant ( $360 \mathrm{~nm}$ Ex and $450 \mathrm{~nm} \mathrm{Em}$ ) after staining with the Hoescht dye. Standard solutions of salmon sperm DNA were used for calibration. The results were expressed as $g$ of DNA strands/mg proteins. ${ }^{11}$ A Synergy 4 MultiDetection Microplate Reader (BioTek Instruments, Inc., USA) was used for protein content, LPO and DNA strandbreaks measurements.

The Comet assay (alkaline version) was performed according to the procedure described by Singh et al. (1988) $)^{12}$ and modified as follows: $20 \mu \mathrm{L}$ of hemolymph collected from the mussel muscle were mixed with $20 \mu \mathrm{L}$ of $1 \%$ low melting point agarose prepared in phosphate buffered saline at $37^{\circ} \mathrm{C}$. This mixture 
was spread on a frosted microscope slide precoated with normal agarose (1\%), and was covered with a $22 \times 22 \mathrm{~mm}$ coverslip (two gels per slide). Coverslips were withdrawn after agarose polymerization $\left(4^{\circ} \mathrm{C}, 5 \mathrm{~min}\right)$, and slides were incubated for $90 \mathrm{~min}$ in a lysing solution (2.5 M NaCl, $0.1 \mathrm{M} \mathrm{Na}_{2} \mathrm{EDTA}, 10 \mathrm{mM}$ Tris, $10 \%$ DMSO, $1 \%$ Triton X100; $\mathrm{pH} 10$ ) at $4{ }^{\circ} \mathrm{C}$ in the dark. The slides were then placed $30 \mathrm{~min}$ in an electrophoresis buffer $(0.3 \mathrm{M} \mathrm{NaOH}$ and $1 \mathrm{mM} \mathrm{Na} \mathrm{EDTA}_{2} \mathrm{pH}>13$ ) to allow the unwinding of DNA. Electrophoresis was carried out at $25 \mathrm{~V}(0.61 \mathrm{~V} / \mathrm{cm})$ and $300 \mathrm{~mA}$ for $24 \mathrm{~min}$. Slides were then washed three times for $5 \mathrm{~min}$ with a neutralization buffer (0.4 M Tris-HCl, pH 7.5) and dried in absolute ethanol. After staining with Sybr Green solution, each slide was viewed by fluorescence microscopy $\left({ }^{*} 400\right)$. Results were gained by a visual scoring system, for which a total of 100 randomly selected cells on each gel were classified as belonging to one of five categories of comets according to the tail and head intensity. ${ }^{13}$

\section{Results and Discussion}

Each week, physicochemical parameters were measured. Water bodies can be differentiated according to the conductivity measurements, allowing to estimate the plume dispersion (Table 1).

After 30 days of caging, survival rate of mussels was not affected, nor the condition index. However, a significant cytotoxic effect was measured in hemocytes collected in mussels caged in Effluent and DS 4 sites. This cytotoxic effect can be directly correlated with the toxicity of the effluent. Significant genotoxic impacts were observed in mussels exposed to the effluent discharge (site Effluent) whatever the genotoxicity endpoint used (Figure 2). This result was correlated with an increase in lipid peroxidation, compared to upstream response. The correlation between biomarkers responses were analyzed by Spearman correla-
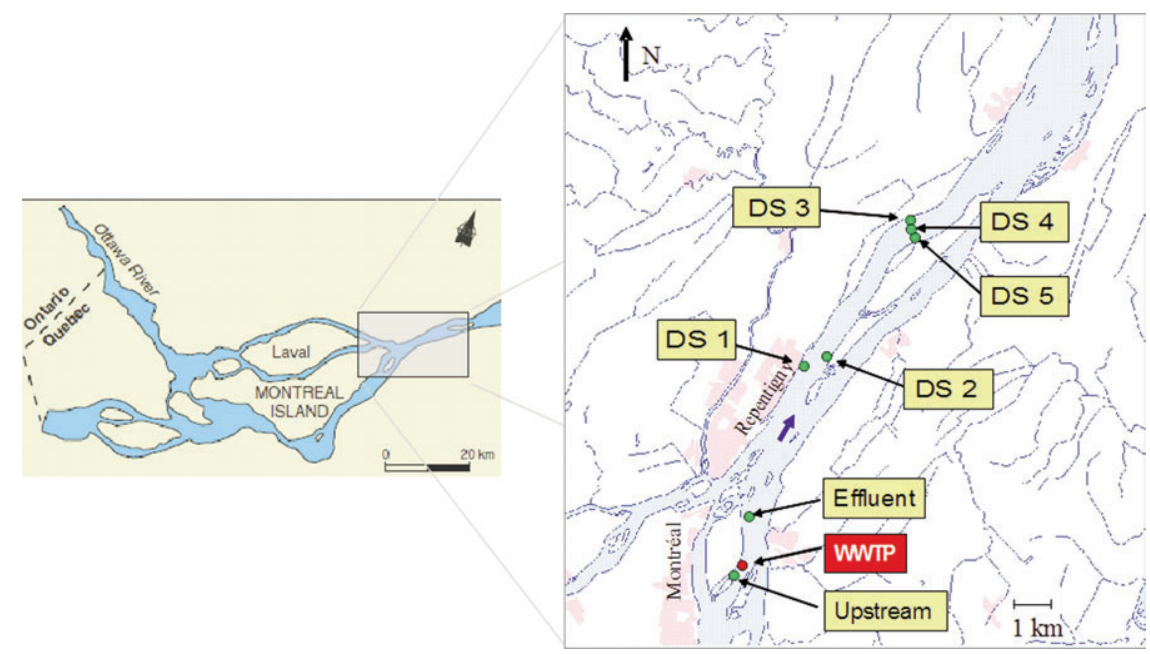

Figure 1. Location map of the study area showing the 7 studied sites where mussels were caged (green points): Upstream, Effluent, Downstream: DS 1, DS2 (10 km downstream the effluent input), DS 3, DS 4, DS 5 (20 km downstream the effluent).
(A)

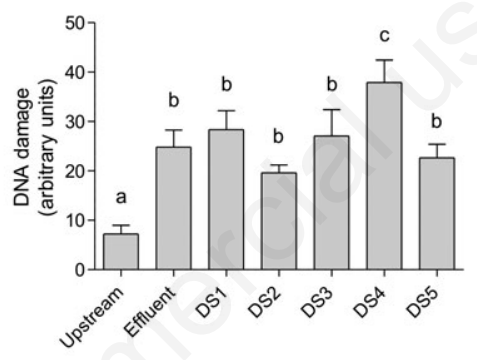

(C)

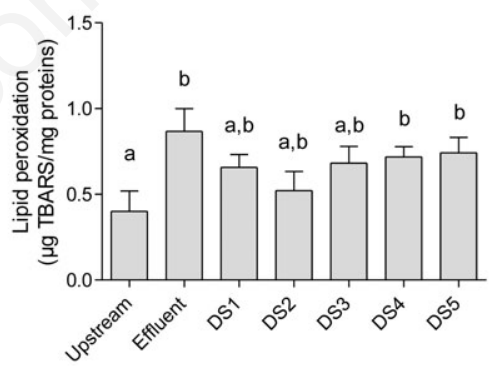

(B)

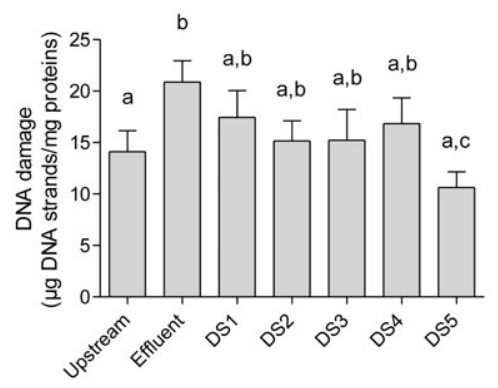

Figure 2. Biomarker responses in hemocytes. (A) DNA damage detected by the Comet assay, (B) DNA damage measured as DNA strands by alkaline precipitation, $(C)$ Lipid peroxidation of hemocytes membranes. Results are expressed as mean $\pm \mathrm{SD}$, $\mathbf{n}=8$. Differences between sites were tested using one-way ANOVA and Mann Whitney $U$ test. Different letter indicates significant difference $(P<0.05)$.

Table 1. Water characteristics at the different sites and summary of biological parameters.

\begin{tabular}{|c|c|c|c|c|c|c|c|c|}
\hline Sites & $\begin{array}{l}\text { Depth } \\
\text { (m) }\end{array}$ & $\begin{array}{c}\text { Temperature } \\
\left({ }^{\circ} \mathrm{C}\right)\end{array}$ & $\mathrm{pH}$ & $\begin{array}{l}\text { Conductivity } \\
\left(\mathrm{pS} \mathrm{cm}^{-1}\right)\end{array}$ & $\begin{array}{l}\text { Suspended matter } \\
\left(\mathrm{mg} \mathrm{L}^{-1}\right) \\
\text { in surface water }\end{array}$ & $\begin{array}{c}\text { Survival rate } \\
(\%)\end{array}$ & $\begin{array}{l}\text { Condition } \\
\text { index } \\
\left(\mathrm{mm} \mathrm{g}^{-1}\right)\end{array}$ & $\begin{array}{c}\text { Hemocyte } \\
\text { viability (\%) }\end{array}$ \\
\hline Upstream & $2.7 \pm 0.0$ & $24.4 \pm 0$ & $8.77 \pm 0$ & $271 \pm 0$ & $4 \pm 0.8$ & 100 & $0.70 \pm 0.08$ & $83.8 \pm 7.2$ \\
\hline Effluent & $2.0 \pm 0.1$ & $23.8 \pm 1.0$ & $7.7 \pm 0.1$ & $331 \pm 2$ & $11 \pm 2.4$ & 100 & $0.65 \pm 0.09$ & $70.0 \pm 12.7^{*}$ \\
\hline Downstream 1 & $4.5 \pm 0.4$ & $23.9 \pm 1.7$ & $7.97 \pm 0.29$ & $143 \pm 14$ & $8 \pm 0$ & 100 & $0.71 \pm 0.22$ & $83.8 \pm 7.8$ \\
\hline Downstream 2 & $6.3 \pm 0.2$ & $23.9 \pm 0.4$ & $8.02 \pm 0.12$ & $280 \pm 1$ & $4 \pm 0$ & 100 & $0.62 \pm 0.19$ & $86.6 \pm 6.5$ \\
\hline Downstream 3 & $1.4 \pm 0$ & $24.9 \pm 0.4$ & $7.82 \pm 0.02$ & $161 \pm 2$ & $11.5 \pm 3.7$ & 100 & $0.63 \pm 0.14$ & $82.3 \pm 7.3$ \\
\hline Downstream 4 & $3.7 \pm 0.5$ & $24.5 \pm 0.2$ & $8.15 \pm 0.02$ & $276 \pm 6$ & $4.5 \pm 0.4$ & 95 & $0.67 \pm 0.11$ & $73.7 \pm 6.7^{*}$ \\
\hline Downstream 5 & $3.2 \pm 0.3$ & $24.0 \pm 0.8$ & $8.28 \pm 0.12$ & $280 \pm 2$ & $3.5 \pm 0.4$ & 100 & $0.69 \pm 0.16$ & $79.3 \pm 6.0$ \\
\hline
\end{tabular}

*Denotes statistically significant difference $(\mathrm{P}<0.05)$ compared to control values (Mann Whitney $\mathrm{U}$ test). 
tion. The hemocytes viability was significantly correlated to DNA damage (Comet assay) and LPO (Pearson coefficient $=0.41$ and 0.37 respectively). These results highlight the effect of the chemical contamination from the municipal effluent input. A positive correlation was also found between DNA damage and LPO results (Pearson coefficient=0.37). The genotoxic impact of a municipal effluent had previously been stressed in Elliptio complanata in a laboratory study where increasing concentrations of effluents altered the mussel DNA (determined by the alkaline precipitation assay) and DNA metabolism highlighted by changes in key enzymes for purine and pyrimidine synthesis (dehydrofolate reductase and aspartate transcarbamoylase) and catabolism of purines (xanthine oxido-reductase). ${ }^{4}$ Increases in DNA damage revealed by the Comet assay and in membrane lipid peroxidation were still measured in mussels encaged $20 \mathrm{~km}$ downstream the effluent discharge despite a massive flow rate in the St Lawrence River. The induction factor of DNA damage between upstream site and the effluent site reached 3.4 whereas at the furthest downstream site in the plume dispersion (DS 4) a 5.3 -fold increase was reached. At DS4, this was associated with low suspended matter content in the surface water. Since hydrophobic genotoxic agents are mostly adsorbed to suspended particulate matter, ${ }^{14}$ the dissolved fraction of contaminants increase along the dispersion plume with the decrease of suspended matter. A fraction of low $\mathrm{K}_{\mathrm{ow}}$ hydrophilic genotoxicants such as pharmaceuticals and pesticides could be suspected to engender additional DNA damage at this site. The results also underlined the importance of the dissolved phase exposure route for mussels compared to the particulate one as previously shown on caged Elliptio complanata exposed to metals. ${ }^{15}$ It is noteworthy that caged organisms at the same distance from the effluent but in a different water body exhibited lower or no effect depending on the biomarker studied. This was particularly observed between the sites DS 4 and DS 5 . According to these results, water bodies could be differentiated between the north and the south shore according to their genotoxic impact, correlated with the presence of effluent dispersion plume. DNA integrity measurement in caged mussels confirms previous findings on the genotoxicity of municipal effluents where the Comet assay represents a sensitive method for assessing the impacts of municipal wastewaters. ${ }^{16}$ Interestingly, an increase in DNA damage revealed by the Comet assay was found in mussels caged in DS 1 compared to upstream site, despite the absence of the effluent dispersion plume of interest at DS1 site. Due to the DS1 location near the shore, this result suggests that a release of genotoxicants could originate from another known municipal WWTP located nearby the site. Finally, the water bodies' toxicity could be highlighted according to their genotoxicity although a chemical characterization of the water samples would reinforce this result. Although the improvement of the wastewater treatment, effluent discharge is responsible for the input of a complex mixture of contaminants, some of them leading to genotoxicity and oxidative stress in freshwater mussels. Previous experiments using caged Elliptio complanata downstream a municipal effluent have stressed a modulation of immune response and induction of detoxification metabolism. ${ }^{3}$ The present study confirmed the relevancy of the caging approach to investigate the short term ecotoxicological effects of municipal effluent.

\section{References}

1. Ohe T, Watanabe T, Wakabayashi K. Mutagens in surface waters: a review. Mutat Res 2004;567:109-49.

2. Joss A, Siegrist H, Ternes TA. Are we about to upgrade wastewater treatment for removing organic micropollutants? Water Sci Technol 2008;57:251-5.

3. Farcy E, Gagné F, Martel L, Fortier M, Trépanier S, Brousseau P, et al. Short-term physiological effects of a xenobiotic mixture on the freshwater mussel Elliptio complanata exposed to municipal effluents. Environ Res 2011;111:1096-206.

4. Gagné F, Bouchard B, André C, Farcy E, Fournier M. Evidence of feminization in wild Elliptio complanata mussels in the receiving waters downstream of a municipal effluent outfall. Comp Biochem Phys C 2011;153:99-106.

5. Bouchard B, Gagné F, Fortier M, Fournier M. An in-situ study of the impacts of urban wastewater on the immune and reproduc- tive systems of the freshwater mussel Elliptio complanata. Comp Biochem Physiol C Toxicol Pharmacol 2009;150:13240.

6. Jha AN. Genotoxicological studies in aquatic organisms: an overview. Mutat Res Fund Mol M 2004;552:1-17.

7. Cheng TC. Bivalves. In: Ratcliffe NA, Rowley AF, eds. Invertebrates blood cells. London: Academic Press; 2001. pp 233-300.

8. Bradford MM. A rapid and sensitive method for the quantitation of microgram quantities of protein utilizing the principle of protein dye binding. Anal Biochem 1976;72:248-54.

9. Wills ED. Evaluation of lipid peroxidation in lipids and biological membranes. In: Snell K, Mullock B, eds. Biochemical toxicology: a practical approach. Washington, DC: IRL Press; 1987. pp 127-150.

10. Olive PL. DNA precipitation assay: a rapid and simple method for detecting DNA damage in mammalian cells. Environ Mol Mutagen 1988;11:487-95.

11. Gagné F, Blaise C. Evaluation of the genotoxicity of environmental contaminants in sediments to rainbow trout hepatocytes Environ Toxic Water 1995; 10:217-29.

12. Singh NP, McCoy MT, Tice RR, Schneider EL. A simple technique for quantitation of low levels of DNA damage in individual cells. Exp Cell Res 1988;175:184-91.

13. Collins AR, Dobson VL, Dušinská M, Kennedy G, Št tina R. The comet assay: What can it really tell us? Mutat Res Fund Mol M 1997;375:183-93.

14. White PA, Rasmussen JB, Blaise C. Genotoxic substances in the St. Lawrence system I: industrial genotoxins sorbed to particulate matter in the St. Lawrence, St. Maurice, and Saguenay Rivers, Canada. Environ. Toxicol Chem 1998;17:286-303.

15. Gagnon C, Gagné F, Turcotte P, Saulnier I, Blaise C, Salazar M, et al. Exposure of caged mussels to metals in a primarytreated municipal wastewater plume. Chemosphere 2006;62:998-1010.

16. Lacaze E, Devaux A, Mons R, Bony S, Garric J, Geffard A, et al. DNA damage in caged Gammarus fossarum amphipods: a tool for freshwater genotoxicity assessment. Environ Poll 2011;159:1682-91. 